\title{
ISOLATION AND CLONING OF cDNA OF GENE ENCODING FOR METALLOTHIONEIN TYPE 2 FROM MELASTOMA AFFINE
}

\author{
SUHARSONO ${ }^{1,2}$, NIKEN TRISNANINGRUM ${ }^{1}$, LULUT DWI SULISTYANINGSIH ${ }^{1}$, \\ UTUT WIDYASTUTI ${ }^{1,2}$
}

${ }^{1}$ Research Center for Bioresources and Biotechnology, and

${ }^{2}$ Department of Biology, Bogor Agricultural University

Indonesia

\begin{abstract}
Metallothionein is an important protein for detoxifying heavy metal ions. This research was conducted to isolate and clone cDNA of gene encoding for metallothionein type 2 from Melastoma affine. Total RNA was isolated from young leaves. Total cDNA was synthesized from the total RNA by reverse transcription. The MaMt2 cDNA was successfully isolated by PCR technique. The MaMt2 cDNA was inserted into pGEM-T Easy and the recombinant plasmid was successfully introduced into Escherichia coli DH5 $\alpha$. DNA sequencing analysis showed that this cDNA is full length consisting of $246 \mathrm{pb}$ encoding 81 amino acid residues. This cDNA is identical to mRNA of AtMt2 from Arabidopsis thaliana. It does not contain any restriction sites found in the cloning sites of pGEM-T Easy. The deduced protein of MaMT2 contains 14 cysteine residues distributed in the Cys-Cys, Cys-X-Cys, and Cys-X-X-Cys motifs.
\end{abstract}

Key words: cDNA, metallothionein, Melastoma affine, cloning, cysteine

\section{INTRODUCTION}

Gene isolation has a very important role in the genetic improvement of crops. The genes can be isolated from genetic resources coming from microorganism, plants, or animals. Melastoma malabathricum L. or M. affine D. Don is an aluminum hyperaccumulator plant (Watanabe et al. 2005) and used as an indicator for acid soil. Since it is tolerant to acid and $\mathrm{Al}$ stresses, it is very important to use this plant as genetic resources for tolerance genes to acid and $\mathrm{Al}$ stresses. Tolerant plants to $\mathrm{Al}$ are very important to increase agricultural production in Indonesia because Indonesia has about 47.5 million hectares of pod soil yellow-red land which have low $\mathrm{pH}$ and high solubility of Al (CSAR 1997).

Metallothionein (MT) is a protein having low molecular weight, around 4-8 $\mathrm{kDa}$ (Vallee 1991). It is constituted of 45-48 amino acid residues containing 12-17 conserved cysteine residues (Kagi 1991). Cobbett and Goldsbrough (2002) 
have classified MT into four types based on distribution of cysteine residues in the $\mathrm{C}$-terminal and $\mathrm{N}$-terminal regions. Type 1 of $\mathrm{MT}$ is consisted of two domains with metal binding motif Cys-X-Cys. Type 2 is composed of two domains with metal binding motif in combination among Cys-Cys, Cys-X-X-Cys, and Cys-X-Cys. Type 3 is also called as a phytochelatin (PC) and has a structure of ( $\gamma$-Glu-Cys)n-Gly, whereas type 4 contains rich in cysteine in repeated sequence.

MT can bind heavy metal, and has an important role in the detoxifying of some heavy metal ions (Clemens 2000, Hall 2002), like Zn (Nigel et al. 1996). The expression of BjMT2 in A. thaliana increased the seedling tolerance against Co and $\mathrm{Cd}$ (Zhigang et al. 2006).

The expression of $M t 2$ gene is induced by Al stress in wheat (Snowden et al. 1995), by $\mathrm{H}_{2} \mathrm{O}_{2}$ and metal ion in rice (Zhou et al. 2005), by Cu and $\mathrm{Co}$ in $A$. thaliana (Zhou and Goldsbrough 1995), by drought stress in wild watermelon (Akashi et al. 2004) but it is down regulated by small GTPase OsRac I in rice (Wong et al. 2004). Mt2 gene had been isolated from soybean (Kawashima et al. 1991), Vicia faba (Foley and Singh 1994), rice (Hsieh et al. 1995) and broccoli (Yang et al. 2000).

This research has the objective to isolate and to clone the cDNA of gene encoding for metallothionein type 2 from $M$. affine L. Since the expression of $M t 2$ is induced by Al stress (Snowden et al. 1995), we suppose that the over-expression of this gene can increase the plant tolerance to Al. By this reason, this gene can be used to improve genetically the tolerance of important plant to $\mathrm{Al}$ by over-expressing the $\mathrm{Mt} 2$ gene.

\section{MATERIALS AND METHODS}

\section{Materials}

Young leaves of $M$. affine were used as plant material. pGEM-T Easy (Promega) was used as cloning vector. Escherichia coli DH5 $\alpha$ was used as a host for recombinant plasmid. Primers of $A c t F$ (ATGGCAGATGCCGAGGATAT), and ActR (CAGTTGTGCGACCACTTGCA) designed based on complete nucleotide sequence of a soybean actin gene (Shah et al. 1982, GenBank V00450) were used to amplify exon1-exon2 of $\beta$-actin as a control of cDNA. Primers of MF (TCGAGAAAAATGTCTTGCTGTG), and M7R (CTTCACTTGCAGGTGCA AGG) designed based on Arabidopsis thaliana MT2A mRNA (GenBank NM_1117733) were used to isolate $M t 2 \mathrm{cDNA}$ of $M$. affine.

\section{Total RNA isolation}

Young leaves $(1 \mathrm{~g})$ were ground with pestle in the mortar in the presence of 0.3 g sands and $10 \mathrm{ml}$ warm extraction buffer (2\% CTAB, 2\% PVP 25000, $100 \mathrm{mM}$ Tris$\mathrm{HCl} \mathrm{pH} 8,20 \mathrm{mM}$ EDTA, $1.4 \mathrm{M} \mathrm{NaCl}, 1 \% \beta$-mercaptoethanol) previously heated at $65^{\circ} \mathrm{C}$. This suspension was poured into $20 \mathrm{ml}$ centrifuge tube, and incubated at $65^{\circ} \mathrm{C}$ for 10 minutes, and then added by $10 \mathrm{ml}$ of chloroform:isoamylalcohol (24:1). After vortexing to mix this suspension, the tube was centrifuged at $42000 \mathrm{xg}$ (rotor SW 11 , Sorvall Ultra Pro 80 ), $4^{\circ} \mathrm{C}$ for 10 mins. The upper liquid phase were collected and added by 0.25 volumes of $10 \mathrm{M} \mathrm{LiCl}$. After incubation at $-32^{\circ} \mathrm{C}$ for 2.5 hours, this suspension was centrifuged at $42000 \mathrm{xg}$ (rotor SW11, Sorvall Ultra Pro 80), $4^{\circ} \mathrm{C}$ for 
10 mins. The pellet containing total RNA was suspended by adding $500 \mathrm{ml}$ TE (10 $\mathrm{mM}$ Tris- $\mathrm{HCl} \mathrm{pH} 7.4,10 \mathrm{mM}$ EDTA). This total RNA suspension was extracted by adding $1 \mathrm{x}$ volume of phenol $\mathrm{pH}$ 9, then vortexing and centrifuging at $14000 \mathrm{rpm}$ (Jouan BR4i) at $20^{\circ} \mathrm{C}$ for 10 mins. The total RNA suspension was recovered from the upper phase, and then extracted by $1 \mathrm{x}$ volume of phenol:chloroform:isoamylalcohol (25:24:1), then centrifuged at $15000 \mathrm{rpm}, 20^{\circ} \mathrm{C}$ for $10 \mathrm{~min}$. The total RNA contained in upper phase was precipited by adding 0.25 volume of $10 \mathrm{M} \mathrm{LiCl}$, and incubated at $-32^{\circ} \mathrm{C}$ overnight. This total RNA suspension was centrifuged at $15000 \mathrm{rpm}, 4^{\circ} \mathrm{C}$, $10 \mathrm{~min}$. Total RNA pellet was washed by $500 \mathrm{ml}$ ethanol $70 \%$ and centrifuged at $15000 \mathrm{rpm}, 4^{\circ} \mathrm{C}, 10 \mathrm{~min}$. After drying with vacuum dryer total RNA was added by DEPC treated $\mathrm{H}_{2} \mathrm{O}$ to make a suspension.

\section{Synthesis of total cDNA}

Total cDNA was synthesized by mixing $5 \mu \mathrm{g}$ total RNA, $4 \mu \mathrm{l} 5 \mathrm{x}$ buffer SuperScript III Reverse Transcriptase (Invitrogen), 20 pmol oligo(dT), 4 mM dNTP, 10 mM DTT, $1 \mathrm{U}$ enzyme SuperScript ${ }^{\mathrm{TM}}$ III RTase dan DEPC treated $\mathrm{H}_{2} \mathrm{O}$ in the final volume of $20 \mu \mathrm{l}$. Reverse transcription to synthesize total cDNA was carried out at $52^{\circ} \mathrm{C}$ for 50 mins by using PCR machine (MJ Research TM 100). The purity of total cDNA was verified by using PCR with specific primers of for cDNA of exon 1 -exon 2 of $\beta$-actin. The composition of PCR was $1 \mu$ total cDNA, $1 \mathrm{x}$ taq buffer, $40 \mathrm{mM} \mathrm{MgCl}, 4 \mathrm{mM}$ dNTP mix, 20 pmol $A c t F$ primer, 20 pmol $A c t R$ primer, 4\% DMSO, $0.75 \mathrm{U}$ taq DNA polymerase (Toyobo) and $\mathrm{H}_{2} \mathrm{O}$ in the final volume of $20 \mu \mathrm{l}$. The condition of PCR was pre-PCR $95^{\circ} \mathrm{C}, 5$ mins, denaturizing at $94^{\circ} \mathrm{C}, 30$ seconds, annealing at $57^{\circ} \mathrm{C}, 30$ seconds, extension at $72^{\circ} \mathrm{C}, 1.5 \mathrm{~min}$, and post-PCR at $72^{\circ} \mathrm{C}, 5 \mathrm{~min}$. The PCR was conducted for 35 cycles.

\section{Isolation of MaMt2 cDNA by PCR}

The composition of PCR was $1 \mu$ total cDNA, $2 \mu$ l 10x buffer taq, $4 \mathrm{mM}$ dNTP, 20 pmol MF primer, 20 pmol M7R primer, 4\% DMSO, 0.75 U taq DNA polymerase (Toyobo) and $\mathrm{H}_{2} \mathrm{O}$ in the final volume of $20 \mu \mathrm{l}$. The PCR was conducted for 35 cycles at $95^{\circ} \mathrm{C}, 5 \mathrm{~min}$. for pre-PCR, $94^{\circ} \mathrm{C}, 30$ seconds for denaturising, $60^{\circ} \mathrm{C}$, 30 seconds for annealing, $72^{\circ} \mathrm{C}, 1.5 \mathrm{~min}$. for extension and $72^{\circ} \mathrm{C}, 5 \mathrm{~min}$. for postPCR.

\section{Cloning MaMt2 cDNA into pGEM-T Easy}

MaMt 2 cDNA of PCR product $(3 \mathrm{ml})$ was mixed with $10 \mathrm{ng}$ pGEM-T Easy (Promega), 3 U T4 DNA ligase (Promega), 1x ligation buffer, and $\mathrm{H}_{2} \mathrm{O}$ in the final volume of $10 \mu \mathrm{l}$. The reaction was carried out at $4^{\circ} \mathrm{C}$ overnight. The ligation product was introduced into E. coli DH5 $\alpha$ as described by Suharsono (2002).

\section{Selection of $E$. coli containing $M a M t 2$}

E. coli containing $M a M t 2$ was selected based on the resistance to ampicillin and blue-white selection. The insert of MaMt2 in the white ampicillin resistant colony was confirmed by PCR-colony. The colony was picked up by tooth-picker,

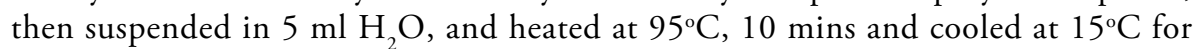
5 mins. The suspension was added by $1.5 \mu \mathrm{l} 10 \mathrm{x}$ buffer taq, $3 \mathrm{mM} \mathrm{dNTP,} 15 \mathrm{pmol}$ 
$M F$ primer, 15 pmol M7R primer, 4\% DMSO, $0.75 \mathrm{U}$ enzim taq DNA polymerase (Toyobo). PCR was conducted in the same condition as for $M a M t 2 \mathrm{cDNA}$ isolation. The insert of MaMt $2 \mathrm{cDNA}$ was also confirmed by plasmid DNA isolation as described by Suharsono (2002). The plasmid DNA was digested by EcoRI at $37^{\circ} \mathrm{C}$ for 2 hours.

\section{Analysis of cDNA}

DNA was sequenced by using automated DNA sequencer ABI Prism 3100 version 3.7. Local alignment analysis of cDNA was carried out by using BLAST2 program (http://www.ebi.ac.uk/blast2) (Mount 2001). Restriction sites in the cDNA of MaMt2 was analyzed by NEB Cutter program (http://www.firstmarket.com/cutter/ cut2.html).

\section{RESULTS AND DISCUSSIONS}

\section{Total RNA isolation}

Total RNA of $M$. affine had been successfully isolated from young leaves and the efficiency of isolation was $118-213 \mu \mathrm{g}$ RNA/g leaves. The absorbent ratio of $\lambda 260 / \lambda 280$ was $1.4-1.6$. It showed that these total RNAs were probably contaminated by remaining protein and/or phenol. The purity of total RNA is high if the $\lambda 260$ / $\lambda 280$ absorbent ratio is around 1.8-2.0 (Saunders and Parker 1999).

Electrophoresis analysis in formaldehyde denaturized agarose gel in the MOPS buffer showed that the total RNA contained two prominent bands. These two bands were corresponded to the integrated 28s and $18 \mathrm{~s}$ ribosomal RNA (Figure 1). Since the total RNA contained integrated $28 \mathrm{~s}$ and $18 \mathrm{~s}$ rRNA, the integrity of total RNA was also high, and could be used as template for total cDNA synthesis. The integrity of mRNA is very important to isolate the full length of coding sequence of DNA. To use the gene for genetic improvement by over-expression, the full length of gene is indispensible.

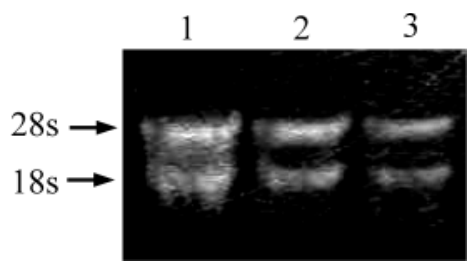

Figure 1. Electrophoresis of total RNA of $M$. affine isolated in different time from young leaves. 1=10 o'clock, 2=12 o'clock, and 3=14 o'clock.

\section{Total cDNA synthesis}

By using total cDNA as template and specific primer for cDNA of $\beta$-actin, amplification by PCR resulted to 450 bp band corresponding to cDNA of exon 1-exon2 of $\beta$-actin (Figure 2). The result showed that the total cDNA had been successfully synthesized and this total cDNA was free from the contamination by genomic DNA. If genomic DNA contaminated the total cDNA, the amplification of $\beta$-actin would result to two bands, $450 \mathrm{bp}$ and $550 \mathrm{bp}$, corresponding to amplified cDNA and 
genomic DNA respectively. The 550 bp DNA was resulted from the amplification of exon 1 -intron-exon 2 of $\beta$-actin, and the size of intron beetwen exon 1 and exon 2 is around $100 \mathrm{bp}$ (Shah et al. 1982). This intron is spliced during the mRNA synthesis, so cDNA derived from mRNA does not contain this $100 \mathrm{bp}$ intron.

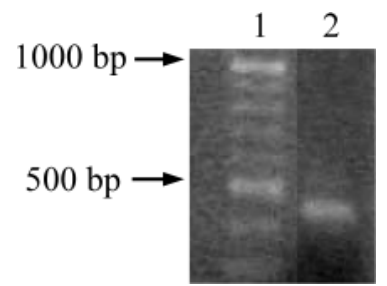

Figure 2. Amplification of exon1-exon2 cDNA of $\beta$-actin. $1=100$ bp DNA marker, $2=$ exon1-exon2 cDNA of $\beta$-actin

cDNA is very important for genetic engineering of eucaryotic organisms. This DNA represents the coding region of gene. The size of cDNA is equal or smaller than the corresponding DNA of gene. Since the size is smaller, the expression of gene by using cDNA is more efficient than by using DNA of gene. Therefore, the cDNA of gene is more preferable than DNA although the isolation of gene by using cDNA is more difficult than by using DNA in eucaryotic organisms.

\section{Isolation and cloning of $\mathrm{MaMt} 2 \mathrm{cDNA}$}

PCR by using total cDNA as template and MF and M7R as primers of resulted around 250 bp DNA (Figure 3). This result was the same as predicted because the size of $M t 2$ in several plant species is around $250 \mathrm{bp}$ as found in soybean (Kawashima $e t$ al. 1991), wheat (Snowden and Gardner 1993), A. thaliana (Zhou and Goldsbrough 1994), and rice (Zhou et al. 2006).

This cDNA was then inserted in pGEM-T Easy, and the recombinant plasmid DNA was successfully introduced into E. coli $\mathrm{DH} 5 \alpha$ shown by the white colonies grown in the selective media containing ampicillin, X-gal and IPTG. pGEM-T Easy plasmid contains lacZ in its cloning site (CS). Only E. coli containing plasmid can survive in the media containing ampicillin and only $E$. coli containing recombinant plasmid can grow in white colony in the presence of X-gal and IPTG in the media. The insertion of cDNA in the lac $Z$ found in the cloning site caused the inactivation of lac $Z$ to be expressed. On the other hand, if there are no insertions in the lac $Z$, this gene is expressed to produce $\beta$-galactosidase and this enzyme will convert uncolored $\mathrm{X}$-gal to become blue color. As a result, the color of colonies which do not contain the recombinant plasmid is blue. 


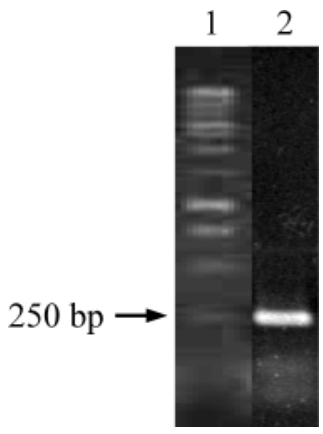

Figure 3. cDNA of MaMt2 resulted by PCR

To confirm the inserted cDNA of $M a M t 2$, the white colony was picked up and used as template for PCR-colony. The PCR-colony resulted 250 bp DNA (Figure 4). The plasmid DNA was successfully isolated from this white colony. The digestion of this plasmid DNA with EcoRI resulted two fragments of DNA, one is $250 \mathrm{bp}$ and the other is $3 \mathrm{~kb}$ corresponding to the cDNA of MaMt2 and pGEM-T Easy cloning vector, respectively (Figure 4). This result showed that the white colony contained $M a M t 2$ cDNA found in the pGEM-T Easy.

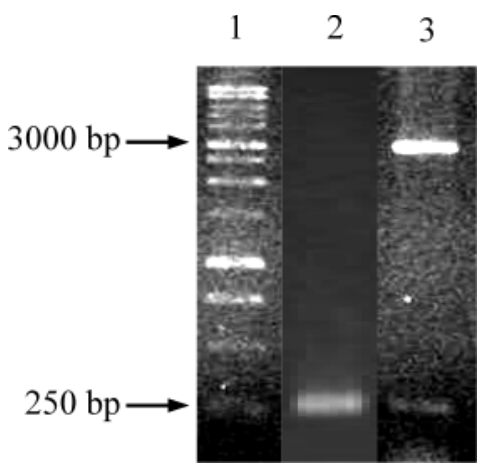

Figure 4. Analysis of cDNA insert in pGEMT-Easy recombinant by PCR-colony (2) and EcoRI digestion (3). $1=1 \mathrm{~kb}$ plus DNA marker.

\section{Analysis of cDNA of MaMt2}

Based on sequencing from SP6 primer, the recombinant pGEM-T Easy contained insert DNA of 257 bp consisted of 246 bp open reading frame encoding for 81 amino acid residues (Figure 5). Alignment analysis by BLASTn showed that this cDNA had similarity of $100 \%$ with mRNA of AtMt2A of A. thaliana (Accession: NM_111773.3), 90\% with mRNA of BjMt2 of Brassica juncea (Y10850.1), 89\% with mRNA of BrMt of B. rapa (D78498.1), 88\% with mRNA of BcMt of B. camprestris (L31940.1), and $88 \%$ with mRNA of BoMt2 of B. oleracea (AF200712.1). This alignment analysis showed that the cDNA isolated in this research is a full length of MaMt2 of M. affine containing start and stop codons. 


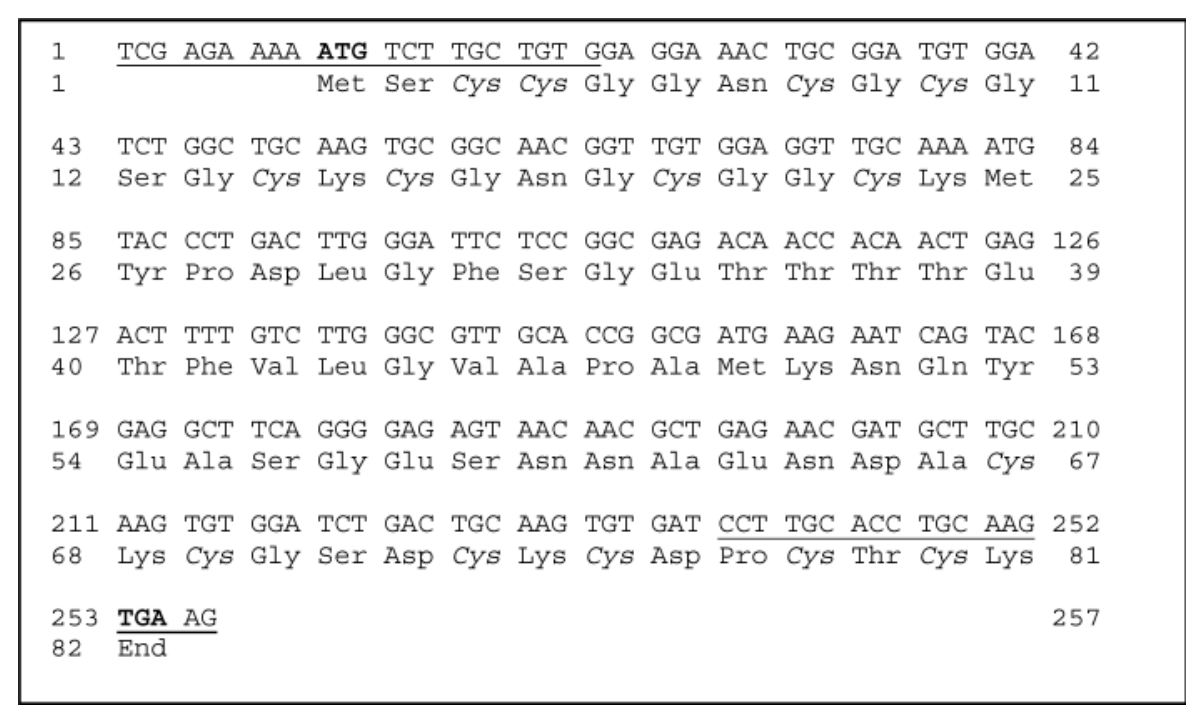

Figure 5. Nucleotide and deduced amino acid sequences of MaMt2. Underline sequences indicate the forward and complementary reverse primers of used to isolate MaMt2, bold letters indicate start and stop codons respectively, italic letters indicate the cys amino acids.

Restriction site analysis showed that MaMt2 contains BbvI, BsaBI, BtsCI, TseI, FokI, ApeKI, CspCI, HpyCH4III, PshAI, BsrFI, SgrAI, AcuI, BtgZI, MboII, $S f a$ NI, Cac8I and Hpy188I sites (Figure 6). These sites cannot be used to clone and engineer $M a M t 2$ because they can cut $M a M t 2$ in two or more fragments. Fortunately, $M a M t 2$ does not contain any restriction site found in CS of pGEM-T Easy. It means that, all restriction sites found in CS can be used to isolate the MaMt2 cloned into pGEM-T Easy.

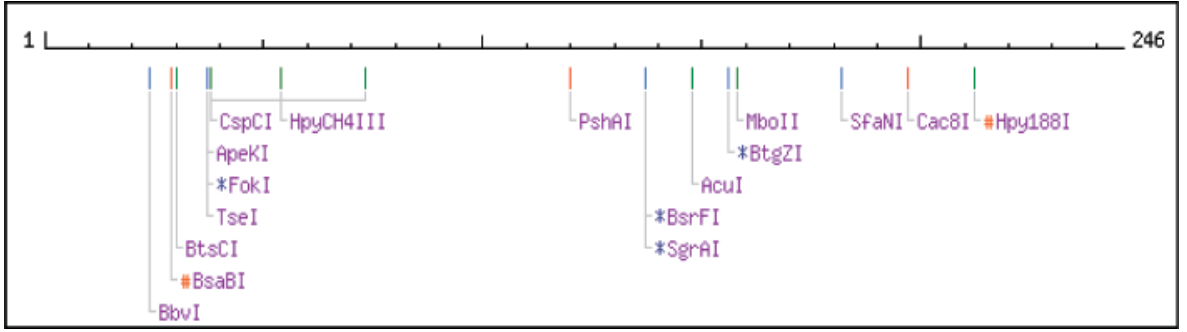

Figure 6. Restriction site map of MaMt2.

To perform genetic engineering, the information of the nucleotide sequence and the restriction sites of the gene are indispensable. The nucleotide sequence information can be used to modify the sequence by in vitro directed mutagenesis. The information of restriction sites of the gene is very important to decide the restriction enzymes which will be used to cut off the gene and then to fuse with other genes or expression elements as promoter and terminator. 
Deduced amino acid residues demonstrate that MaMT2 contains 81 amino acid residues with 14 cysteine residues. This result is in accordance with the number of amino acid residues and cysteine residues of MT type 2 from several plants (Kojima 1991). Analysis of cysteine sequence motif showed that MaMT2 has a motif Cys-Cys (3rd-4th residues), Cys-X-Cys (8-10, 14-16, 67-69, 73-75, 78-80) and Cys-X-X-Cys (20-23) (Figure 5). This specific Cys sequence demonstrates that MaMT2 has the similar motif of Cys distribution with MT type 2 of several plants (Robinson et al. 1993; Cobbett and Goldsbrough 2002).

The full length of MaMt2 cDNA isolated in this report is the first MT family genes isolated from $M$. affine as the indigenous plant in tropical rain forest like Indonesia. Since this plant is very tolerant to $\mathrm{Al}$, the $M a M t 2$ can be used to improve genetically the important plant for Indonesia as soybean. The genetic improvement can be done by over-expressing $M a M t 2$. We are now targeting the over-expression of $\mathrm{MaMt} 2$ in soybean to improve the resistance to $\mathrm{Al}$ by using strong promoter. In the near future, we also would like to over-express this MaMt2 cDNA in Jatropha curcas.

\section{CONCLUSIONS}

The total RNA of $M$. affine had been isolated and converted into total cDNA. The full length of cDNA of MaMt2 gene had been isolated from this total cDNA and cloned into pGEM-T Easy. This MaMt2 cDNA contains 246 bp and encodes 81 amino acids. MaMT2 contains 14 Cys amino acids distributing in Cys-Cys, Cys-XCys, and Cys-X-X-Cys motifs. This full length of MaMt2 cDNA is the first cDNA of $M t$ family gene isolated from $M$. affine. It can be applied to improve genetically the Al tolerance of plant.

\section{ACKNOWLEDGMENTS}

We would like to thank BIOTROP-SEAMEO and Directorate of Research and Community Services, Directorate General of Higher Education, Ministry of National Education, Republic of Indonesia for the financial support of this research by contract agreement no. 13.1/PSRP/SP-PEN/IV/2005 and SPK 008/HIKOM/ $\mathrm{DP} 2 \mathrm{M} / 2008$, respectively.

\section{REFERENCES}

Akashi K., N. Nishimura, Y. Ishida, and A. Yokota. 2004. Potent hydroxyl radical-scavenging activity of drought-induced type-2 metallothionein in wild watermelon. Biochemical and Biophysical Research Communications, 323: 72-78.

Clemens, S. 2001. Molecular mechanisms of plant metal tolerance and homeostasis. Planta 212: 475-486.

Cobbett C, and P. Goldsbrough. 2002. Phytochelatins and metallothioneins: roles in heavy metal detoxification and homeostasis. Annual Review of Plant. Biology, 53: 159-182. 
CSAR (Center for Soil and Agroclimate Research). 1997. Statistik Sumberdaya Lahan/Tanah Indonesia dan Agroklimat. Badan Litbang Departemen Pertanian. Jakarta.

Foley R.C., and K.B. Singh. 1994. Isolation of a Vicia faba metallothionein-like gene: expression in foliar trichomes. Plant Molecular Biology, 26: 435-444.

Hall J.L. 2002. Cellular mechanism for heavy metal detoxification and tolerance. Journal of Experimental Botany, 53 (366): 1-11.

Hsieh H.M., W.K. Liu, and P.C. Huang. 1995. A novel stress-inducible metallothionein-gene from rice. Plant Molecular Biology, 8: 381-389.

Kagi J.H.R. 1991. Overview of metallothionein. Methods in Enzymology , 205: 613-626.

Kawashima I., Y. Inokuchi, M. Chino, M. Kimura, and N. Shimizu. 1991. Isolation of a gene for a metallothionein-like protein from soybean. Plant Cell Physiology, 32: 913-916.

Kojima Y., P.A. Binz, and J.HR. Kagi. 1999. Nomenclature of metallothionein: proposal for a revision. In: Metallothionein IV, C. Klaassen. Birkhauser-Verlag. Basel.

Mount D.W. 2001. Bioinformatics: Sequence and Genome Analysis. New York: Cold Spring Harbor Laboratory Press.

Robinson N.J., A.M. Tommey, C. Kuske, and P.J. Jackson. 1993. Plant metallothionein. Journal of Biochemistry, 295: 1-10.

Nigel J. R., J.R. Wilson, and J. S. Turner. 1996. Expression of the type 2 metallothionein-like gene MT2 from Arabidopsis thaliana in $\mathrm{Zn}^{2+}$-metallothionein-deficient Synechococcus PCC 7942: putative role for MT2 in $\mathrm{Zn}^{2+}$ metabolism. Plant Molecular Biology, 30: 1169-1179.

Saunders G.C., and H.P. Parker. 1999. Analytical Molecular Biology: Quality and Validation. Teddington: LGC Press.

Snowden K.C., and R.C. Gardner. 1993. Five genes induced by aluminum in wheat (Triticum aestivum L) roots. Plant Physiology, 103: 855-861.

Snowden K.C., K.D. Richard, and R.C. Gardner. 1995. Aluminium-induced genes induction by toxic metals, low cadmium, wounding and patterns of expression in root tips. Plant Physiology, 107: 341348.

Shah D.M., R.C. Hightower, and R.B. Meagher. 1982. Complete nucleotide sequence of a soybean actin gene. Proceedings National Academy of Science, USA, 79 (4): 1022-1026.

Suharsono. 2002. Konstruksi pustaka genom kultivar Slamet. Hayati , 9(3): 67-70.

Vallee B.L. 1991. Introduction of metallothionein. Methods in Enzymology, 205: 3-7.

Watanabe T., S. Misawa, and M. Osaki. 2005. Aluminum accumulation in the roots of Melastoma malabathricum, an aluminum-accumulating plant. Canadian Journal of Botany, 83: 1518-1522.

Wong H.L., T. Sakamoto, T. Kawasaki, K. Umemura, and K. Shimamoto. 2004. Down-regulation of metallothionein, a reactive oxygen scavenger, by the small GTPase OsRac I in rice. Plant Physiology, 135: 1447-1456.

Zhigang A., L. Cuijie, Z. Yuangang, D. Yejie, A. Wachter, R. Gromes, and T. Rausch. 2006 Expression of BjMT2, a metallothionein 2 from Brassica juncea, increases copper and cadmium tolerance in Escherichia coli and Arabidopsis thaliana, but inhibits root elongation in Arabidopsis thaliana seedlings. Journal of Experimental Botany, 57 (14): 3575-3582.

Yang C.Y., Y. Lin, and J.F. Shaw. 2000. Cloning and characterization of a cDNA encoding a MT2 type metallothionein from Broccoli (Brassica oleracea cv. Green king) florest. Plant Physiology, 122: 1457. 
Isolation and cloning of cDNA from Melastoma affine - Suharsono et al.

Zhou J., and P.B. Goldsbrough. 1995. Structure, organization and expression of the metallothionein gene family in Arabidopsis. Molecular and General Genetics, 248: 318-328.

Zhou G., Y.F. Xu, and J.Y. Liu. 2005. Characterization of a rice class II metallothionein gene: tissue expression patterns and induction in response to abiotic factors. Journal of Plant Physiology, 162: 686696. 
Thank you for evaluating AnyBizSoft PDF Splitter.

A watermark is added at the end of each output PDF file.

To remove the watermark, you need to purchase the software from

http://www.anypdftools.com/buy/buy-pdf-splitter.html 